\title{
Reasons smokers give for stopping smoking: do they relate to success in stopping?
}

\author{
Elizabeth Gilpin, John P Pierce, Jerry Goodman, David Burns, Donald Shopland
}

\begin{abstract}
Objective - To determine the frequency and distribution of reasons that smokers give for stopping smoking, and whether any type of reason is associated with a greater likelihood of success than any other.
\end{abstract}

Design-Univariate and multivariate analyses of reasons for stopping smoking by demographic characteristics, success in stopping by demographic characteristics, and success in stopping by reasons for stopping (adjusting for demographic variables).

Subjects-3788 current and former smokers who had stopped in the five years before the interview as part of the 1987 National Health Interview Survey (Cancer Control Supplement), a population survey of non-institutionalised adults in the United States.

Main outcome measures-Reasons for stopping and percentage of successful quitters (abstinent for at least one year at the time of the survey).

Results - Respondents mentioned health reasons as a motivating factor most frequently (health reasons, $62 \%$; social reasons, $22 \%$; cost, $9 \%$; lost desire, $5 \%$ ). Important relations were found between demographic factors and reasons cited and between demographic factors and success in stopping. After adjustment for differences in demographic variables related to success in stopping, smokers citing only health, social, or cost reasons had about the same likelihood of success. However, smokers citing a combination of health and social reasons had a higher likelihood of stopping successfully than had those citing only social or cost reasons, but their likelihood of success was not increased compared with those citing only health reasons or loss of desire.

Conclusion-Even though the social acceptability of smoking has been increasingly emphasised in the campaign against smoking, the health message should continue to have a major role. Smokers who cite a social reason for stopping are more likely to stop successfully if they feel that they are stopping for their own health as well.

(Tobacco Control 1992; 1:256-63)
Introduction

The prevalence of smoking in the United States was $28 \%$ in 1988 , and if the current downward trend of the past 30 years continues, it will decrease at a constant rate to $22 \%$ in the year $2000.1^{1}$ One of the objectives of the US Public Health Service for the year 2000 is to reduce smoking prevalence to $15 \% .^{2}$ To achieve this goal, it will be necessary to markedly accelerate the rate of successful quitting among smokers. Currently, over 30\% of smokers try to stop in any given year. ${ }^{3}$ However, only between $5 \%$ and $10 \%$ are able to maintain abstinence for one year, ${ }^{4,5}$ and this long term success rate does not seem to have changed much since the $1970 \mathrm{~s}^{6}$ Thus, the problem is one of preventing relapse.

The decision of smokers to try to stop and their willingness to struggle to maintain the effort reflect their motivation. The stronger the motivation is at the time of stopping smoking the higher the likelihood of success; studies of smoking cessation in relation to cardiac disease show particularly high rates of success. ${ }^{7,8}$ Also, those who do not relapse may be motivated to stop for different reasons than those who do relapse. If this is true, knowing which reasons are cited by successful quitters may help in the development of more effective approaches for motivating smokers to stop smoking.

Public health interventions to motivate people to stop smoking have been based on three themes: health consequences, social influences, and cost. ${ }^{9}$ The first anti-smoking approach, typified by the field in the 1960 s and 1970 s, was to rely almost solely on publicising the health consequences of smoking. As developed in the health belief model, ${ }^{10,11}$ this theme assumes that before a behavioural change will occur for health reasons, individuals must believe that their behaviour is seriously and negatively affecting their health.

The role of social influences in behaviour change is explained in social learning theory. ${ }^{12}$ This theory emphasises that there are three reciprocal influences determining whether a particular behaviour will be performed in a given situation. These are the social environment, the behaviour itself, and the individual's cognitions. The environment is responsible for several social influences on an individual. These include both social cues from other people about what is considered to be acceptable behaviour and advice from health professionals on what is unhealthy behaviour. The 
environmental tobacco smoke issue has placed the social theme of stopping smoking for the sake of others high on the list of themes in anti-smoking campaigns over the past five years.

An almost universal rule in economics is that the demand for a commodity declines as its price increases. Several econometric studies have confirmed that this relation holds for cigarettes. ${ }^{3}$ One method of decreasing cigarette consumption is to increase the excise tax on cigarettes, as has been done recently (1989) in California, where voters passed a tax increase that effectively doubled the previously combined state and federal excise tax on a pack of cigarettes to a total of 51 cents, ${ }^{13}$ and in cigarettes now exceeds $\$ C 2.00 .^{14}$

In this paper we examine data from the noninstitutionalised US population collected as part of the 1987 National Health Interview Survey concerning the different motivational reasons that smokers had for attempting to stop smoking between 1983 and 1987 . We also consider which reasons or combinations of reasons given for attempting to stop are most highly related to successful stopping.

$$
2
$$

Data on reasons for stopping smoking were obtained from smokers who had smoked for at least five years and had tried to stop smoking in the five years before their interview as part of the 1987 National Health Interview Survey. In the Cancer Control Supplement of this survey 22043 people aged 18 years and older were interviewed in detail about their recent smoking and quitting behaviour.

This survey is a cross sectional, populationbased survey in which the United States is divided into geographically defined areas called primary sampling units. The units are stratified, and one or more of them are randomly selected within each stratum. Within each selected sampling unit a small cluster of households is randomly chosen for interview. Members of these households are first contacted by post and then interviewed in person. The questions on tobacco use are answered by the individuals themselves. When a respondent cannot be interviewed in person this section of the survey is administered by telephone. The survey sample is weighted to reflect the age, sex, and racial distribution of the United States population and to adjust for the survey design features. Further details concerning the survey design have been published. ${ }^{15,16}$ The response rate for this survey was $87 \%$.

Ever smokers were defined as those who had smoked at least 100 cigarettes in their life. Current smokers were defined as those who answered "yes" to the question "Do you smoke cigarettes now?" Recent quitting history was obtained by asking former smokers Canada, where the excise tax on a pack of

ever tried to stop "When was your last serious attempt to quit smoking?"

In this study we are concerned only with addicted smokers who had tried to stop in the recent past (which we defined as five years before the survey). Thus, only smokers who had smoked for at least five years were considered. We defined a successful quitter as a person who had been abstinent for at least one year at the time of the survey $(n=1172)$. We defined a failed quitter as a current smoker who had attempted to stop in the past five years $(n=2616)$. Given the different circumstances relating to smoking during pregnancy, ${ }^{17}$ we decided to consider such individuals ineligible for the analysis.

Of the total survey population of 22043 , we identified 3788 people (1172 former and 2616 current smokers) who could be identified as meeting the eligibility criteria outlined above (figure). Altogether 1222 people were excluded because relevant information was not available (801 with unknown smoking status, 228 with unknown smoking duration, and 193 with unknown date for trying to stop smoking) to assess eligibility. Thus the final study population analysed represents $75 \%$ $(3788 /(3788+1222))$ of those potentially eligible.

Demographic variables analysed in this study included age, sex, race, education, income, and marital status.

\section{STUDY POPULATION} "About how long has it been since you last smoked cigarettes regularly?" and by asking current smokers who indicated that they had

\section{REASONS FOR QUITTING}

Both former and current smokers were asked the following open-ended question: "Thinking about the time(s) you tried to quit smoking, please tell me the reasons you had for trying to quit." Respondents could give more than one reason and all reasons given were coded into 13 predefined categories, including pregnancy (see previous section). A miscellaneous category was used for all responses that did not fit into any of the predefined categories. No descriptive information was retained for these other miscellaneous reasons. For the present analysis the reasons for stopping smoking were classified in the following manner (see table 1). Any health symptom or concern about either present or future health was classified as a health reason; pressure from family or friends, advice from a doctor, setting a good example, effect of smoking on others, and "dirty habit" were classified as social reasons; and cost of cigarettes, loss of desire to smoke, and the other miscellaneous category were treated separately.

\section{STATISTICAL METHODS}

For variance estimation and significance testing, we used the SUDAAN computer program, which incorporates the intricacies of the design and population weighting procedures of the National Health Interview Survey. ${ }^{18}$ Logistic regressions (program LOGISTIC of SUDAAN) were used to examine the relation of demographic characteristics to each of the four main classes of reasons 


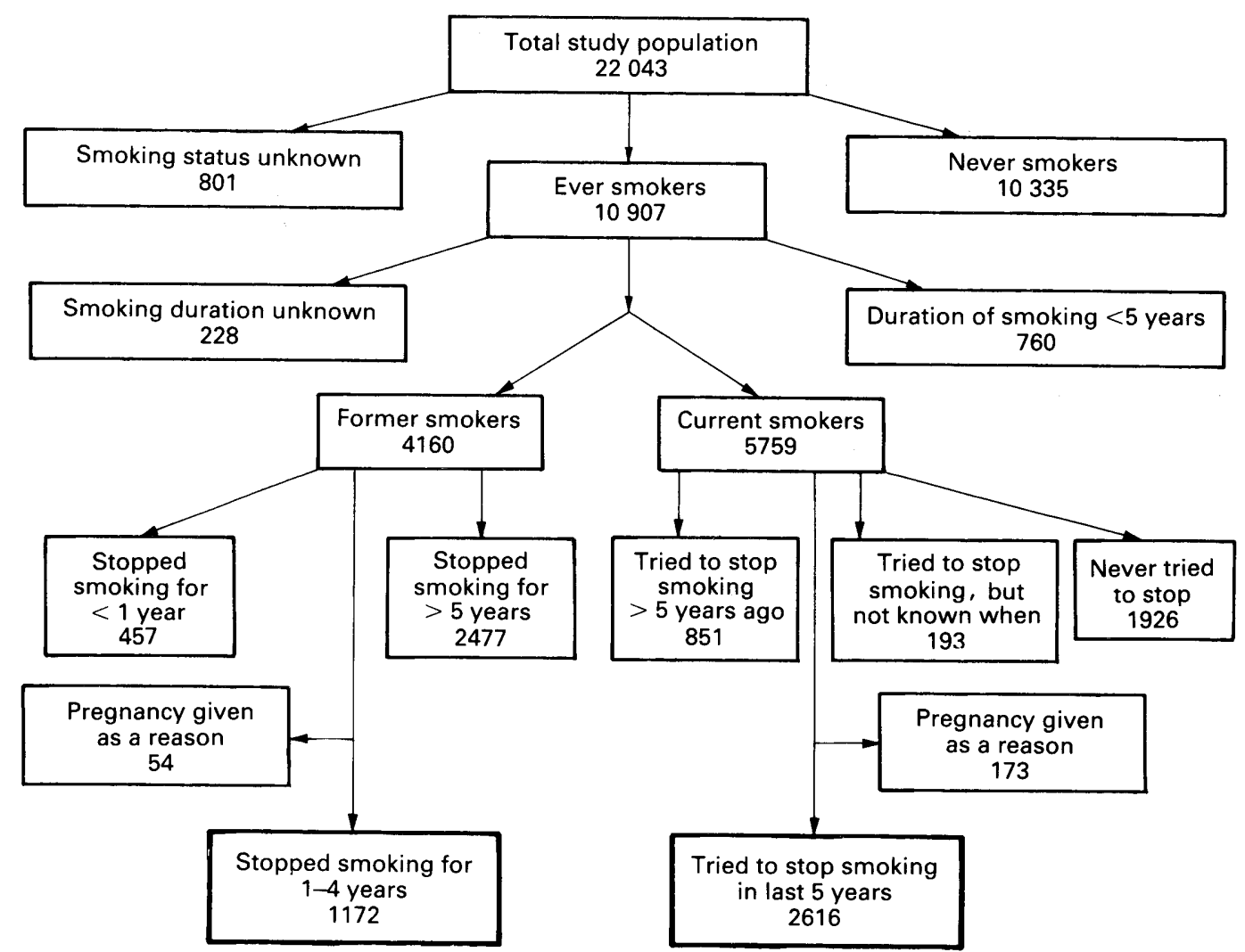

Derivation of study population from respondents to the 1987 National Health Interview Survey

(health, social, cost, and loss of desire) for stopping smoking. We report odds ratios, as determined by the regression coefficients, for independently significant demographic variables.

With additional logistic regressions, we modelled the likelihood of successfully stopping smoking with respect to categories of reasons given, adjusting for demographic characteristics. We categorised the reasons for stopping smoking into nine mutually exclusive categories: health only, social only, cost only, loss of desire only, miscellaneous only, health and social, health and cost, other combinations including loss of desire, and other combinations excluding loss of desire. A separate analysis was made using each category in turn as the reference category for comparison with all the other categories.

\section{Results}

REASONS FOR TRYING TO STOP SMOKING

Table 1 presents the weighted distribution of respondents by sex for individual reasons (including "other") to stop smoking that were coded as part of the questionnaire. Of the reasons cited, $81 \%$ could be specifically categorised; only $19 \%$ were categorised as "other miscellaneous." Health-related reasons (four reasons) were the most frequently mentioned (about $62 \%$ of the study sample) as motivating factors. Nearly half of those citing health reasons were concerned about the effects of their smoking on their present health (reasons 1 and 2). Social reasons (five reasons) were mentioned by $19.3 \%$ of men and $23.9 \%$ of
Table 1 Reasons mentioned by men and women for stopping smoking. Values are weighted percentages $(S E)$

$\begin{array}{ccc} & \text { Men } & \text { Women } \\ \text { Reason } & (n=1800) & (n=1988)\end{array}$

Health

Health symptom/problem

Present health

Future health

Both present and future health

Social

Pressure from family/friends

Advice from doctor

Setting example for children

Effect of smoking on others

Dirty habit

Cost of cigarettes

Lost desire to smoke

Other miscellaneous

$62 \cdot 6(1 \cdot 3) \quad 62 \cdot 4(1.5)$

$\begin{array}{ll}62.6(1.3) & 62.4(1.5) \\ 19 \cdot 1(1.1) & 18.6(1.1)\end{array}$

$13.1(1.0) \quad 14.0(1.0)$

$25.0(1.1) \quad 26 \cdot 1(1.3)$

$16.8(1 \cdot 1) \quad 16 \cdot 0(1.0)$

$19.3(1.1) \quad 23.9(1.2)$

$\begin{array}{r}19 \cdot 3(0 \cdot 7) \quad 11 \cdot 2(0.8) \\ \hline \cdot 1(0.5)\end{array}$

$\begin{array}{rr}9 \cdot 1(0.7) & 11 \cdot 2(0.8) \\ 3.1(0.5) & 3.1(0.5)\end{array}$

$\begin{array}{ll}3 \cdot 1(0.5) & 3 \cdot 1(0.5) \\ 2 \cdot 2(0.4) & 3.6(0.5)\end{array}$

$\begin{array}{ll}2 \cdot 2(0.4) & 3 \cdot 6(0.5) \\ 2 \cdot 3(0.4) & 4.0(0.6)\end{array}$

$4 \cdot 8(0.6) \quad 6.3(0.6)$

$7.8(0.7) \quad 9.3(0.8)$

$\begin{array}{rr}5.1(0.6) & 4.6(0.6) \\ 18.9(1.2) & 19.7(1.4)\end{array}$

Data from the 1987 National Health Interview Survey (Cancer Control Supplement), a United States population-

based survey. Included were people who tried to stop

smoking in the five years before the survey.

women (overall by $21.5 \%$ of the sample), and pressure from family or friends was the social reason most often mentioned (by $9.1 \%$ of men and $11.2 \%$ of women). The cost of cigarettes as a factor in the decision to stop was mentioned by $7.8 \%$ of men and $9.3 \%$ of women (overall by $8.5 \%$ of the sample), and loss of desire was stated overall by $4.9 \%$. Only $3.2 \%$ gave no reason for stopping.

\section{REASON CATEGORY AND DEMOGRAPHIC}

\section{CHARACTERISTICS}

Table 2 presents the percentages of respondents citing health and social reasons by demographic subgroup. There was no significant age trend for citing health or social 


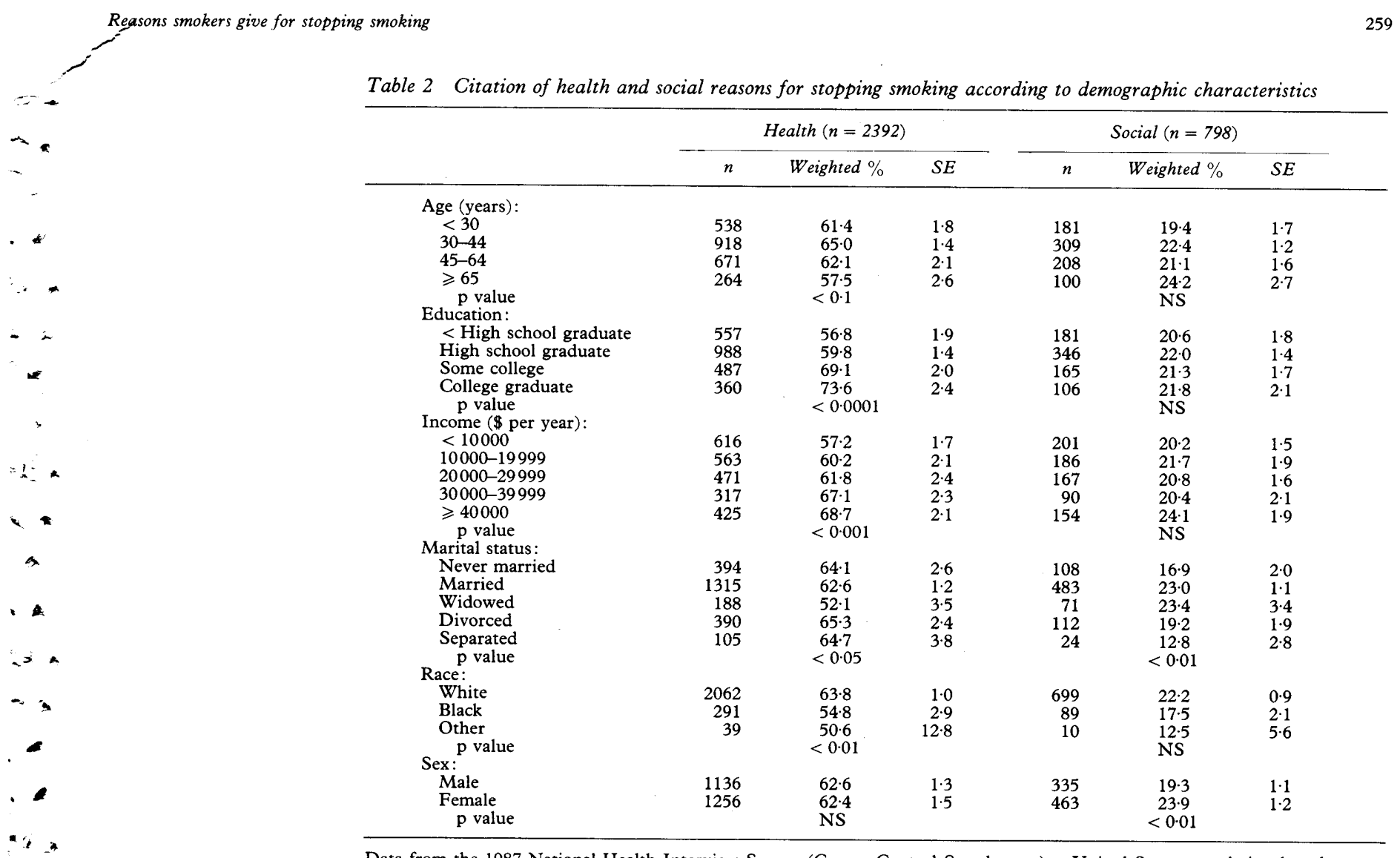

Data from the 1987 National Health Interview Survey (Cancer Control Supplement), a United States population-based survey. Included were people who tried to stop smoking in the five years before the survey.

reasons. The percentage of those citing health reasons for quitting increased with the amount of formal education received and with reported family income. There were also differences with marital status and with race. Whites $(63.8 \%)$ cited health reasons more often than did either blacks $(54.8 \%)$ or people of other races $(50 \cdot 6 \%)$. Although, women cited social reasons significantly more often than did men, the difference was not large $(23.9 \%$ and $19.3 \%$, respectively). Marital status was also related to mention of social reasons for stopping; the percentages were higher for married and widowed people than for those in the other categories. The percentage of respondents citing cost as a reason for stopping varied inversely with income $(p<0.05)$, marital status $(p<0.05)$, and race $(\mathrm{p}<0.05)$. Cost as a reason was cited nearly twice as often by respondents in the lowest-income category as it was by those in the highest-income category; however, even in the lowest-income category, fewer than $11 \%$ of the respondents cited cost as a reason. The only factor related to citing loss of desire to smoke was age $(p<0.05)$, with younger respondents more likely to give this reason than older respondents.

The logistic regression analyses allowed us to evaluate the relation of each demographic characteristic to category of reason for stopping smoking with adjustment for each of the other demographic characteristics. Education $(\mathrm{p}<0.0001)$ was by far the most important factor related to citing health as a reason to stop smoking, but income was also independently important. Each education group was $14 \%$ more likely than the next less educated group to cite health as a reason, and on average each higher income group was $9 \%$ more likely than the next lowest. For the social reason category, sex $(p<0.002)$ and marital status $(p<0.02)$ emerged as significant independent variables. The adjusted odds for a woman to cite social reasons for stopping smoking cigarettes were 1.34 times those for a man. The only significant influence on cost as a reason to stop proved to be income $(\mathrm{p}<0.004)$ : people at a lower income level were $16 \%$ more likely than those in the next highest level to cite cost as a reason to quit.

\section{SUCCESS IN STOPPING}

Success in stopping varied according to all the demographic factors considered (univariate analysis, table 3 ). When considered jointly in a logistic regression, age $(\mathrm{p}<0.0001)$ was by far the most important independent factor followed by educational level $(p<0.001)$ and to a lesser extent by marital status and race $(\mathrm{p}<0.05)$.

Quitting success rate varied according to the category or combination of reasons given (univariate analysis, table 4). When only one category of reason was stated, loss of desire was associated with the highest success rate $(45.3 \%)$ followed by health $(33.6 \%)$ and social $(30.0 \%)$ reasons. Cost as the only reason had about the same rate of success $(21.3 \%)$ as having no reason $(22.4 \%)$. When health and social reasons were mentioned together with possibly other reasons (excluding loss of desire), the success rate increased slightly to $36.1 \%$. Other multiple categories (both in- 
Table 3 Univariate analysis of success at stopping smoking by demographic characteristics

\begin{tabular}{|c|c|c|c|}
\hline \multirow[b]{2}{*}{ Demographic characteristic } & \multicolumn{3}{|c|}{ Success } \\
\hline & $n$ & Weighted \% & $S E$ \\
\hline \multicolumn{4}{|l|}{ Age (years): } \\
\hline$<30$ & 882 & $21 \cdot 1$ & $1 \cdot 7$ \\
\hline $30-44$ & 1420 & $31 \cdot 2$ & $1 \cdot 4$ \\
\hline $45-64$ & 1036 & $36 \cdot 5$ & $1 \cdot 8$ \\
\hline$\geqslant 65$ & 450 & $44 \cdot 4$ & $2 \cdot 6$ \\
\hline $\mathrm{p}$ value & & $<0.0001$ & \\
\hline \multicolumn{4}{|l|}{ Education: } \\
\hline$<$ High school graduate & 960 & $27 \cdot 1$ & 1.6 \\
\hline High school graduate & 1603 & $28 \cdot 9$ & $1 \cdot 3$ \\
\hline Some college & 738 & $36 \cdot 2$ & $2 \cdot 0$ \\
\hline College graduate & 437 & $42 \cdot 0$ & $2 \cdot 5$ \\
\hline \multicolumn{4}{|l|}{ Income ( $\$$ per year): } \\
\hline$<10000$ & 1404 & $26 \cdot 9$ & $1 \cdot 6$ \\
\hline $10000-19999$ & 920 & $30 \cdot 9$ & $1 \cdot 8$ \\
\hline $20000-29999$ & 743 & $28 \cdot 8$ & $2 \cdot 0$ \\
\hline $30000-39999$ & 468 & $33 \cdot 7$ & $2 \cdot 5$ \\
\hline$\geqslant 40000$ & 610 & $38 \cdot 7$ & $2 \cdot 0$ \\
\hline $\mathrm{p}$ value & & $<0.001$ & \\
\hline \multicolumn{4}{|l|}{ Marital status: } \\
\hline Never married & 621 & $22 \cdot 2$ & $2 \cdot 3$ \\
\hline Married & 2089 & $35 \cdot \overline{2}$ & $1 \cdot 1$ \\
\hline Widowed & 329 & $33 \cdot 8$ & $3 \cdot 0$ \\
\hline Divorced & 583 & 21.6 & 1.9 \\
\hline Separated & 166 & $20 \cdot 3$ & $3 \cdot 5$ \\
\hline p value & & $<0.01$ & \\
\hline \multicolumn{4}{|l|}{ Race: } \\
\hline White & 3193 & $32 \cdot 8$ & $0 \cdot 9$ \\
\hline Black & 529 & $21 \cdot 3$ & $2 \cdot 1$ \\
\hline Other & 66 & $30 \cdot 1$ & $8 \cdot 3$ \\
\hline $\mathrm{p}$ value & & $<0.01$ & \\
\hline \multicolumn{4}{|l|}{ Sex: } \\
\hline Male & 1800 & $33 \cdot 3$ & $1 \cdot 3$ \\
\hline Female & 1988 & $29 \cdot 6$ & $1 \cdot 2$ \\
\hline$p$ value & & 0.07 & \\
\hline
\end{tabular}

Data from the 1987 National Health Interview Survey (Cancer Control Supplement), a United States populationbased survey. Included were people who tried to stop based survey. Included were people who tried
smoking in the five years before the survey.

Table 4 Univariate analysis of success at stopping smoking by reasons for stopping. Values are weighted percentages $(S E)$

\begin{tabular}{|c|c|c|}
\hline Category of reason & Success & $\begin{array}{l}\text { Successful } \\
\text { quitters }\end{array}$ \\
\hline Health only $(\mathrm{n}=1824)$ & $33.6(1.4)$ & $51 \cdot 4(1 \cdot 7)$ \\
\hline Social only $(n=423)$ & $30.0(2.4)$ & $10.8(1.0)$ \\
\hline Cost only $(n=116)$ & $21 \cdot 3(4 \cdot 7)$ & $2.0(0.5)$ \\
\hline Lost desire only $(n=135)$ & $45 \cdot 3(5 \cdot 2)$ & $5 \cdot 1(0 \cdot 7)$ \\
\hline Other only $(n=495)$ & $22.4(2 \cdot 4)$ & $9 \cdot 5(1 \cdot 1)$ \\
\hline Health and social ${ }^{\star}(n=261)$ & $36.1(3.5)$ & $7.9(0.9)$ \\
\hline Health and $\operatorname{cost}^{\star}(n=172)$ & $23 \cdot 3(4 \cdot 1)$ & $3 \cdot 1(0 \cdot 6)$ \\
\hline $\begin{array}{l}\text { Other multiple with lost desire } \\
(\mathrm{n}=51)\end{array}$ & $54.9(8.4)$ & $2.3(0.4)$ \\
\hline $\begin{array}{l}\text { Other multiple excluding lost } \\
\text { desire }(n=188)\end{array}$ & $35.9(4 \cdot 4)$ & $5 \cdot 5(0 \cdot 8)$ \\
\hline No reason given $(\mathrm{n}=123)$ & $22 \cdot 8(4 \cdot 5)$ & $2.4(0.5)$ \\
\hline
\end{tabular}

* At least one of each and possibly others excluding lost desire.

Data from the 1987 National Health Interview Survey (Cancer Control Supplement), a United States populationbased survey. Included were people who tried to stop smoking in the five years before the survey.

cluding and excluding loss of desire) were also associated with higher rates of success. Since a health reason alone was the reason category of nearly half the study respondents $(48.2 \%$, weighted percentage), it is to be expected that the majority of successful quitters would derive from this subgroup (table 4). Also, since the category with the highest success rate (other multiple with lost desire) contained the fewest respondents $(1.3 \%$, weighted percentage), only $2.3 \%$ of the successful quitters were derived from this subgroup.

Logistic regression adjusted for significant demographic variables (age, sex, race, income, and marital status) and allowed us to compare particular categories of reasons with others as predictors of quitting success. After adjustment, health-only, social-only, cost-only, and loss of desire-only were all about equally associated with quitting success, and all were more related than other-only or other multiple (excluding loss of desire). Only the combination of health and social reasons was significantly more related to successful quitting than many of the other reason categories: social-only ( $\mathrm{p}<0.0001)$, cost-only $(\mathrm{p}<0.05)$, other-only $(\mathrm{p}<0.0001)$, health and cost ( $p<0.001$ ), and other multiple (excluding loss of desire) $(\mathrm{p}<0.0001)$.

\section{Discussion}

Two thirds of smokers who reported trying to stop smoking gave their personal health as the main reason: about a fifth indicated that a current health condition had motivated them to stop. About one fifth of the quitters cited social reasons, with pressure from family or friends the major factor. Cost was named as a reason by only $9 \%$ of quitters. The average price of a packet of cigarettes in the United States in 1990 was only $\$ 1.82,{ }^{19}$ which relative to income is cheaper than in any other country in the world. Thus, our finding that cost is not particularly related to success in stopping smoking may not apply in other countries. However, income is related to citing cost as a reason, suggesting that there is validity to the price elasticity argument. If the tax on cigarettes in the United States were to reach the Canadian level, the price of cigarettes would double and we could expect much more cost motivation to stop smoking in this country.

In recalling the reasons that they perform a behaviour people tend to attribute the cause to their own internal decisions rather than to indicate that they were influenced by an external cause. ${ }^{20}$ Therefore, both the social and cost reasons may be under-represented in this study relative to health reasons. More highly educated people were much more likely to indicate that they were stopping for a health reason than were those with less education. Importantly, given the recall biases mentioned above, we believe that someone who did not mention a health reason for stopping smoking when they were given the opportunity to cite multiple reasons, probably does not accept that stopping would be of major benefit to their health. About one third of smokers trying to stop and all smokers who were not actively trying to stop could benefit from a better understanding of the advantages of smoking cessation to their own personal health. Even when individuals do not suffer from overt symptoms of smoking-related diseases, smoking cessation can provide immediate health benefits. ${ }^{21}$ Physicians are in a particularly good position to convey this message and thereby motivate more people to stop. ${ }^{22}$

Social reasons for stopping were mentioned significantly more often by women than by men and more often by those who were married or widowed than those who were single or 
divorced. The major social reason for stopping was pressure from family or friends; this finding suggests either that there is significantly more social pressure on women smokers to quit than there is on men, or that women are more susceptible to such pressure. New campaigns emphasising passive smoking are strategies aimed at motivating people to stop smoking for social reasons.

Success in stopping smoking is known to be associated with sociodemographic variables, ${ }^{23-25}$ and our findings confirm those of other investigators. There was a significant independent relation between success and older age, ${ }^{24}$ higher education, ${ }^{24.25}$ marital status (married and widowed), and white race. ${ }^{23}$ The association with sex was only of borderline significance, which is consistent with national data that showed that the rate of change over time in quit rate for men compared with women was only of borderline significance ${ }^{23}$ and that sex did not discriminate between successful quitters and relapsers. ${ }^{24}$

We then controlled for these known differences in sociodemographic success rates in comparing the effect on success of the different reasons for quitting. Our findings indicated that, after adjustment, loss of desire was not associated with greater success than the other single reasons. This result may be confounded by age; younger people are more likely to mention loss of desire (table 2), and quitting success is lower for younger smokers (table 3 ).

After adjustment, health, social, and cost reasons were about equally related to success, but health and social reasons together had an advantage over social reasons alone and several other reason categories. Thus, those who indicate that they have a social reason for quitting are more likely to be successful if they believe that they are not smoking for the benefit of their own health as well.

During the study period, 1983-7, approximately $60 \%$ of those who smoked tried to stop and about one third of those trying to stop were successful (abstinent for one year or more at the time of the survey). This percentage is considerably higher than the usual 16-20\% success rates at one year estimated for any single quit attempt ${ }^{8}$ and suggests that the respondents had made multiple attempts.

The proportions of respondents citing health, social pressure, or cost as a reason for trying to stop smoking are consistent with those from a small $(n=601)$ survey of nurses in South Carolina. ${ }^{26}$ Health reasons were given most often by nurses who had successfully stopped $(61 \%)$, as well as by those who had cut down on the amount smoked $(90 \%)$; social reasons were the next most frequently cited reason in both groups (about $50 \%$ ); and cost was cited by $29 \%$ of smoking nurses as a reason to cut down on their smoking but was not analysed as a reason for smoking cessation. In that study about $70 \%$ of the respondents had an annual family income of $\$ 20000$ or less, which may account for the relatively higher concern for cost than was observed in our study, in which only $43 \%$ had annual family incomes of $\$ 20000$ or less.
A recent study in Australia showed that a respondent's perceived likelihood to quit smoking was associated with successful stopping. ${ }^{27}$ For 1661 smokers the researchers analysed the relation between perceived likelihood to stop and several other factors, including health and social arguments for smoking cessation. ${ }^{27}$ Smokers were categorised as extremely unlikely, unlikely, likely, or extremely likely to quit smoking within the following three months. These results indicated that health or social reasons alone were not related to the likelihood that a smoker anticipated stopping; across all levels of likelihood to quit, between $10 \%$ and $30 \%$ of respondents cited either health or social reasons to quit. However, respondents who perceived that they were very likely to stop smoking in the near future had a significantly higher rate of acceptance of both health and social arguments (50\% to $60 \%$ ). In our study a combination of health and social reasons was a better predictor of success in stopping smoking than social but not health reasons alone.

This finding has important implications for tobacco control campaigns. Despite the temptation to use messages that emphasise stopping smoking to protect the health of family and friends, an anti-smoking campaign should not forget that such a major change in behaviour is more likely to be successful if the person thinks that their personal health will benefit as well. Although factors motivating smoking cessation in the mid-1980s might have changed by the early 1990s, our results should provide a benchmark for comparisons with future surveys and allow for the assessment of the effects of ongoing public health efforts to motivate smoking cessation.

This study was supported by grant No 1RT245 from the University of California Tobacco-Related Disease Research Program. We thank Dr Deborah Winn and staff of the National Health Interview Survey for their assistance in using the data tapes from their surveys. We also thank Elizabeth Whalen and Tina Kim for help in preparing and editing this paper.

1 Pierce JP, Fiore MC, Novotny TN, Hatziandreu EJ, Davis RM Trends in cigarette smoking in the United States: projections to the year $2000.7 A M A 1989 ; 261: 61-5$.

2 US Public Health Service. Promoting health/preventing disease: year 2000 objectives for the nation. Rockville, Maryland: Department of Health and Human Services, $1989 ; 59$.

3 US Department of Health and Human Services. Reducing the health consequences of smoking: 25 years of progress. A report of the Surgeon General, 1989. Atlanta, Georgia: Centers for Disease Control, Office on Smoking and Health, 1989. (DHHS Publication No (CDC) 89-8411.)

4 Wilson DM, Taylor W, Gilbert JR, et al. A randomized trial of family physician intervention for smoking cessation. $\mathcal{F} A M A$ 1988; 260: $1570-4$.

5 Kottke TE, Brekke ML, Solberg LI, Hughes JR. A randomized trial to increase smoking intervention by physicians: doctors helping smokers, round 1. $7 A M A$ 1989; 261: 2102-6.

6 Hunt WA, Barnett LW, Branch LG. Relapse rates in addiction programs. F Clin Psychol 1971; 27: 455-6.

7 Rigotti NA, Singer DE, Mulley AG, Thibault GE. Smoking cessation following admission to a coronary care unit. $\mathcal{F}$ Gen Intern Med 1991; 6: 305-11.

8 Schwartz JL. Review and evaluation of smoking cessation methods: the United States and Canada, 1978-1985. Bethesda, Maryland: Department of Health and Human Services, 1987. (DHHS Publication No (NIH) 87-2940.)

9 Pierce JP. Progress and problems in the international public health effort to reduce tobacco usage. Ann Rev Public Health 1991; 12: 383-400.

10 Becker MH, Haefner DP, Kasl SV, Kirscht JP, Maiman 
LA, Rosenstock IM. Selected psychosocial models and correlates of individual health-related behaviors. Med Care 1977; 15 (suppl 5): 27-46.

i1 Rosenstock I, Kirscht JP. Why people seek care. In: Stone G, Alder F, Cohen N, eds. Health psychology. San Francisco, California: Jossey-Bass, 1979: 161-88.

12 Bandura A. Social foundations of thought and action : a social cognitive theory. Englewood Cliffs, New Jersey: PrenticeHall, 1986: 1-46.

13 Bal DG, Kizer KW, Felton PG, Mozar HN, Neimery D. Reducing tobacco consumption in California: the development of a statewide anti-tobacco use campaign. fAMA 1990; 12: 1570-4.

14 Collishaw NE, Kaiserman MJ, Rogers B. Monitoring effectiveness of Canada's health-oriented tobacco policies. In: Durston B, Jamrozik K, eds. Tobacco and health 1990: the global war. Perth: Health Department of 1990: the global war. Perth: Health Department of world conference on tobacco and health.)

15 National Center for Health Statistics. Current estimates from the health interview survey. Series 10, No 166. Hyattsville, Maryland: Department of Health, Education, and Welfare, 1987

16 Massey JT, Moore TF, Parson V, Tadros W. Design and estimation for the national health interview survey, 1985-94. Hyattsville, Maryland: National Center for Health Statistics, 1989. (Vital and health statistics; Series 2; No 34.)

17 Fingerhut LA, Kleinman JC, Kendrick JS. Smoking before, during, and after pregnancy. Am $\mathcal{F}$ Public Health 1990; 80: $541-4$

18 Research Triangle Institute. SUDAAN Professional Software for SUrvey DAta ANalysis. Research Triangle
Park, North Carolina: Research Triangle Institute, 1989.

19 Tobacco Institute. The tax burden on tobacco. Historical compilation, 1990. Washington, DC: Tobacco Institute, 1991 : vii.

20 Nisbett R, Ross L. Human inference: strategies and shortcomings of social judgement. Englewood Cliffs, New Jersey: Prentice-Hall, 1980: 200-1.

21 US Department of Health and Human Services. The health benefits of smoking cessation: a report of the Surgeon General, 1990. Atlanta, Georgia: Centers for Disease Control, Office on Smoking and Health, 1990. (DHHS Publication No (CDC) $90-8416$.)

22 Gilpin E, Pierce J, Goodman J, Giovino G, Berry C, Burns D. Trends in physicians giving advice to stop smoking, D. Trends in physicians giving advice to stop smoking,
United States, 1974-87. Tobacco Control 1992; 1: 31-6.

23 Fiore MC, Novotny TE, Pierce JP, Hatziandreu EJ, Patel KM, Davis RM. Trends in cigarette smoking in the $\mathrm{KM}$, Davis RM. Trends in cigarette smoking in the
United States: the changing influence of gender and race United States: the changin

24 Fiore MC, Novotny TE, Pierce JP, et al. Methods used to quit smoking in the United States: do cessation programs help? $\mathcal{F} A M A 1990 ; 263: 2760-5$.

25 Pierce JP, Fiore MC, Novotny TE, Hatziandreu EJ, Davis RM. Trends in cigarette smoking in the United States educational differences are increasing. $7 A M A 1989 ; 261$ : $56-60$.

26 Swenson I, Dalton J. Reasons for smoking cessation among a random sample of North Carolina nurses. Women and Health $1983 ; 8: 33-41$.

27 Pierce JP, Dwyer T, Chamberlain A, Aldrich RN, Shelly JM. Targeting the smoker in an anti-smoking campaign. Prev Med 1987;16: 816-24. 


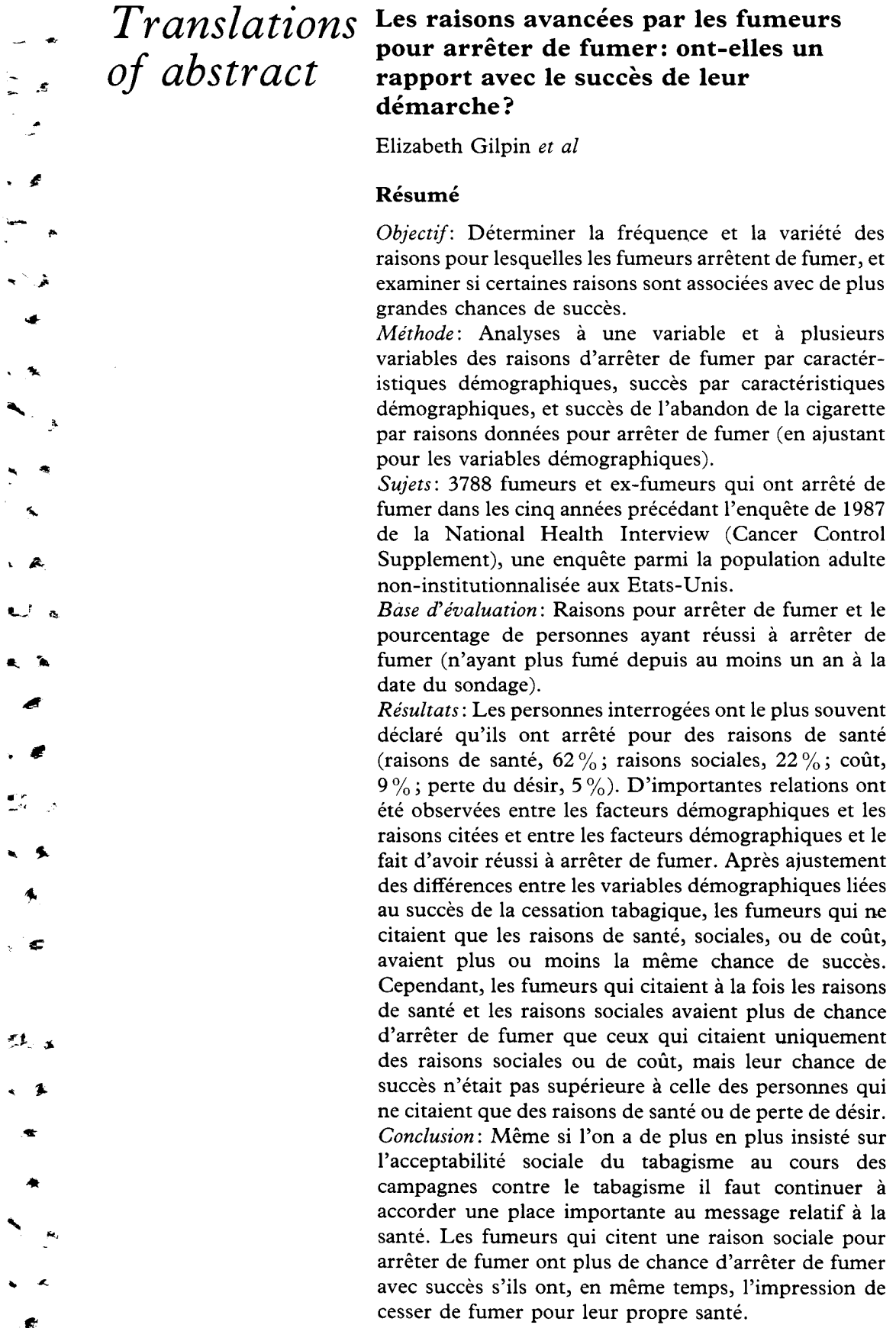

Razones que los fumadores dan para dejar de fumar: ¿se relacionan con el éxito en dejar el tabaquismo?

Elizabeth Gilpin et al

\section{Resumen}

Objetivo: Determinar la frecuencia y la distribución de las razones que los fumadores dan para dejar de fumar, y si algún tipo de razón se asocia con una mayor probabilidad de éxito que las otras.

Diseño: Análisis univariado y multivariado de las razones para dejar de fumar según las características demográficas, el éxito en dejar el tabaquismo según las características demográficas y el éxito en dejar el tabaquismo según las razones para dejarlo (con ajuste para variables demográficas).

Sujetos: En total, 3788 fumadores actuales y exfumadores que habían dejado el tabaquismo en los cinco años anteriores a la entrevista, de la Encuesta Nacional de Salud de 1987 (Suplemento de Control del Cáncer), un estudio de población de adultos no institucionalizados en los Estados Unidos.

Medidas de resultado principales: Las razones para dejar el tabaquismo y el porcentaje de los que tuvieron éxito (por lo menos un año de abstinencia en el momento de la encuesta).

Resultados: Los entrevistados mencionaron con mayor frecuencia las razones de salud como un factor de motivación (razones de salud, $62 \%$; razones sociales, $22 \%$; costo, $9 \%$; pérdida del deseo, $5 \%$ ). Se encontraron relaciones importantes entre los factores demográficos y las razones citadas, y también entre los factores demográficos y el éxito en dejar el tabaquismo. Después del ajuste para las variables demográficas relacionadas con el éxito en dejar el tabaquismo, los fumadores que citaban solo razones de salud, sociales o de costo tuvieron aproximadamente la misma probabilidad de éxito. Sin embargo, los fumadores que citaban una combinación de razones de salud y razones sociales tenían una probabilidad mayor de dejar el hábito con éxito que los que aducían solo razones sociales o de costo, pero esa probabilidad no fue mucho mayor comparada con la de los que mencionaron solo razones de salud o pérdida del deseo.

Conclusion: Aunque la aceptabilidad social del tabaquismo se ha venido recalcando cada vez más en la campaña contra el tabaquismo, el mensaje de salud debe continuar desempeñando el papel protagónico. Los fumadores que citan una razón social para dejar el hábito tienen mayor probabilidad de éxito si creen que lo están haciendo también por su propia salud.

The Chinese translation will be published in the next issue. 